\title{
Repurposing beta3-adrenergic receptor agonists for Alzheimer's disease: Beneficial effects on recognition memory and amyloid pathology in a mouse model.
}

Marine Tournissac ${ }^{1,2}$; Tra-My Vu ${ }^{1,2}$; Nika Vrabic ${ }^{2}$; Clara Hozer ${ }^{3}$; Cyntia Tremblay ${ }^{2}$; Koralie Mélançon ${ }^{2}$; Emmanuel Planel ${ }^{2,4} ;$ Fabien Pifferi $^{3}$; Frédéric Calon ${ }^{1,2 *}$.

${ }^{1}$ Faculté de pharmacie, Université Laval, Québec, Qc, Canada;

${ }^{2}$ Axe Neurosciences, Centre de recherche du CHU de Québec-Université Laval, Québec, Qc, Canada;

${ }^{3}$ UMR 7179 Centre National de la Recherche Scientifique, Muséum National d'Histoire Naturelle, Brunoy, France;

${ }^{4}$ Département de psychiatrie et neurosciences, Faculté de médecine, Université Laval, Québec, Qc, Canada;

*Corresponding Author: Frederic Calon, Centre de recherche du CHU de Québec-Université Laval (Pavillon CHUL), Room T-2-67, 2705 boul. Laurier, Québec (Québec) G1V 4G2, Tel. : (418) 525-4444 x48697. Fax: (418) 654-2761. Email address: frederic.calon@pha.ulaval.ca

Key words: Alzheimer's disease; $\beta 3$-adrenergic receptors; drug repurposing; 3xTg-AD mice; brown adipose tissue; thermogenesis. 


\section{ABSTRACT}

Old age, the most important risk factor for Alzheimer's disease (AD), is associated with thermoregulatory deficits. Brown adipose tissue (BAT) is the main thermogenic driver in mammals and its stimulation, through $\beta 3$-adrenergic receptor ( $\beta 3 A R$ ) agonists or cold acclimation, counteracts metabolic deficits in rodents and humans. Studies in animal models show that AD neuropathology leads to thermoregulatory deficits and cold-induced tau hyperphosphorylation is prevented by BAT stimulation through cold acclimation. Since metabolic disorders and AD share strong pathogenic links, we hypothesized that BAT stimulation through a $\beta 3 A R$ agonist could exert benefits in $A D$ as well.

Here, we show that $\beta 3 A R$ agonist administration (CL-316,243, $1 \mathrm{mg} / \mathrm{kg} /$ day i.p., from 15 to 16 months of age) decreased body weight and improved peripheral glucose metabolism and BAT thermogenesis in both non-transgenic and 3xTg-AD mice. One-month treatment with a $\beta 3 A R$ agonist increased recognition index by $19 \%$ in 16-month-old 3xTg-AD mice compared to pre-treatment (14-month-old). Locomotion, anxiety and tau pathology were not modified. Finally, insoluble $A \beta 42 / A \beta 40$ ratio was decreased by $27 \%$ in the hippocampus of CL-316,243-injected 3xTg-AD mice.

Overall, our results indicate that $\beta 3 A R$ stimulation reverses memory deficits and shifts downward the insoluble $A \beta 42 / A \beta 40$ ratio in 16-month-old 3xTg-AD mice. As $\beta 3 A R$ agonists are being clinically developed for metabolic disorders, repurposing them in AD could be a valuable therapeutic strategy. 


\section{INTRODUCTION}

Old age is the main risk factor of Alzheimer's disease (AD), a neurodegenerative disorder clinically expressed by memory deficits and cognitive dysfunction (Querfurth and LaFerla, 2010; Scheltens et al., 2016). The prevalence of $A D$ is growing fast along with the aging population (Winblad et al., 2016). Yet, the exact pathogenic causes of the sporadic form of the disease are unknown. Despite decades of intense research and clinical trials, there is still no curative treatment for AD. Since AD is a complex and multifactorial disease, with frequent age-related comorbidities, multi-target agents might be advantageous over a single-bullet approach. The undeniable impact of old age on AD incidence indicates that aging triggers etiopathological factors of $A D$; identifying these key factors could provide invaluable clues to the development of novel therapeutic treatments.

Deficits in thermoregulation are among the documented consequences of old age. Although few studies investigated thermoregulation in $A D$ individuals, it is well known that thermoregulatory defects appear in the elderly, the population primarily affected by AD (Degroot and Kenney, 2007; Gomolin et al., 2005; Grassi et al., 2003; Hebert et al., 2013). Mounting evidence now supports the hypothesis that thermoregulation deficits contribute to the development of $A D$ pathology. Spontaneous thermoregulation deficits occurs in mouse models of $A D$ neuropathology, including the triple transgenic (3xTg-AD) mice (Huitrón-Reséndiz et al., 2002; Knight et al., 2013; Sterniczuk et al., 2010; Vandal et al., 2016). Studies in mouse and hibernators repeatedly showed that decreased body temperature leads to increased tau phosphorylation (Arendt et al., 2003; Planel et al., 2007; Stieler et al., 2011). Accordingly, manipulation of external temperature leads to strong modulation of AD neuropathology in mice: cold exposure increases both tau phosphorylation and $\beta$-amyloid $(A \beta)$ pathology and decreases synaptic proteins, while higher temperature reverses memory and anxiety-like behavior and reduced $A \beta 42$ peptide levels in 3xTg-AD mice (Vandal et al., 2016). More recently, our group provided evidence that enhancement of thermogenesis through cold acclimation improves metabolic disorders and protects old 3xTg-AD mice from cold-induced tau phosphorylation (Tournissac et al., 2019). Supporting the link with age, cold-induced tau phosphorylation is potentiated in old mice compared to young mice (Tournissac et al., 2017). Altogether, these observations suggest that thermoregulatory mechanisms could be a potential therapeutic target in AD. 
Beside thermoregulation, metabolic diseases share strong pathogenic links with AD. Indeed, induction of a diabetic phenotype such as glucose intolerance has been repeatedly shown to increase $A D$ neuropathology in a mouse model of AD (Gratuze et al., 2017; Julien et al., 2010; Theriault et al., 2016; Vandal et al., 2014). Central insulin signaling defects and lower brain glucose metabolism are observed in AD (An et al., 2018; Arnold et al., 2018). It is estimated that one out of ten cases of AD is attributable to type 2 diabetes (T2D) (Biessels et al., 2006). These observations logically led to the idea of repurposing T2D drugs in AD (Yarchoan and Arnold, 2014). Insulin, thiazolidinediones and glucagon-like peptide-1 (GLP-1) analog are still the subject of clinical trials in dementia, albeit with mitigated results (Craft et al., 2012; Gejl et al., 2016; J. Liu et al., 2015). Thus, common metabolic targets between both diseases such as thermoregulatory defects are of interest to develop new therapeutic tools in AD.

Brown adipose tissue (BAT) is an essential thermogenic driver in mammals (Cannon and Nedergaard, 2004). The discovery of functional BAT in adults in 2009 has revived research on this tissue (Cypess et al., 2009; Virtanen et al., 2009). The ability of BAT thermogenesis to improve main metabolic disorders is now well-established in young (Hanssen et al., 2015; Ravussin et al., 2014; Schrauwen and van Marken Lichtenbelt, 2016) and old mice (Tournissac et al., 2019). Pharmacological tools have been developed in this direction. In particular, $\beta 3$-adrenergic receptors ( $\beta 3 A R)$ agonists are being extensively used to stimulate $\beta 3 A R$ located on brown adipocytes, thereby leading to lipolysis and UCP1 expression, the main marker of non-shivering thermogenesis (Arch, 2011; Nedergaard et al., 2001). CL-316,243 is a highly specific $\beta 3 A R$ agonist frequently used in metabolic studies in rodents. It has been shown to improve blood glucose metabolism, insulin sensitivity, energy expenditure and to regulate lipids metabolism (Burkey et al., 2000; de Souza et al., 1997; Kim et al., 2006; Kumar et al., 2015; Labbé et al., 2016). Since B3AR agonists can correct metabolic disorders by enhancing BAT activity, they could tackle both T2D and $A D$ at the same time. Importantly, $\beta 3 A R$ agonists have been shown to stimulate BAT activity in humans (Baskin et al., 2018; Cypess et al., 2015) and one of these molecules, mirabegron (Myrbetriq ${ }^{\circledR}$ ), is now approved for the treatment of overactive bladder (Chapple et al., 2014a). Therefore, B3AR agonists could rapidly be tested in humans for dementia.

We hypothesized that pharmacological stimulation of BAT thermogenesis through B3AR agonist treatment could curtail AD neuropathology and improve memory as well as correcting thermoregulatory and metabolic deficits. To verify this hypothesis, 15-month-old non-transgenic (NonTg) and 3xTg-AD mice received daily CL-316,243 (1 mg/kg) or saline injections for a month. 


\section{MATERIAL AND METHODS}

\section{Animals}

The triple-transgenic mouse model of $A D$ (homozygous $3 \times T g-A D ; A P P_{\text {swee }}, P S 1_{M 146 V}, \operatorname{tau}_{\mathrm{P} 301 \mathrm{~L}}$ ) developing both amyloid and tau pathologies in the brain with age was used here (Oddo et al., 2003). We selected 15-month-old 3xTg-AD and NonTg controls, at an age when 3xTg-AD mice have extended plaques and tangles in the brain, as well as cognitive deficits (Belfiore et al., 2018; Bories et al., 2012; St-Amour et al., 2014; Vandal et al., 2015). Animals were produced at our animal facility and all maintained in the same genetic background (C57BL6/129SvJ) by backcrossing every 8-10 generations. Forty-two (42) mice were used for all experiments ( $n=9-12$ mice per group) and 9 mice were added for behavioral and glucose tolerance tests for a total of 51 mice ( $n=9-16$ mice per group).

Mice were housed one to five per cage at a housing temperature of $23^{\circ} \mathrm{C}$, with a $12: 12$ hours light-dark cycle (light phase from 7 a.m. to 7 p.m). Animals had ad libitum access to water and chow (Teklad 2018, Harlan Laboratories, Canada). Only males were used here to avoid temperature variation induced by the estrous cycle of female mice (Weinert et al., 2004). Food consumption was evaluated by weighing the diet of each cage and averaged for each mouse per day per cage every four days during the one-month treatment, and three weeks before the beginning of the experiment. At the end of the experiment, all mice were put under deep anesthesia with ketamine/xylazine intraperitoneal (i.p.) injection (100 mg/kg ketamine, $10 \mathrm{mg} / \mathrm{kg}$ xylazine) and immediately placed under a heating pad to maintain body temperature until complete loss of posterior paw reflex. Then, mice were rapidly sacrificed by intracardiac perfusion with $0.1 \mathrm{M}$ phosphate buffer saline (PBS) solution containing phosphatases (sodium pyrophosphate, $1 \mathrm{mM}$ and sodium fluoride, $50 \mathrm{mM}$ ) and proteases (Sigmafast protease inhibitor tablets, Sigma-Aldrich, St-Louis, USA) inhibitors. All experiments were performed in accordance with the Canadian Council on Animal Care and were approved by the Institutional Committee of the Centre Hospitalier de l’Université Laval (CHUL).

\section{CL-316,243 treatment}

CL-316,243 was selected to stimulate BAT thermogenesis because it is one of the most selective $\beta 3 A R$ agonists in rodents ( $\beta 1: \beta 2: \beta 3=0: 1: 100,000)$ and its safety and efficacy has been confirmed in multiple studies (Bloom et al., 1992; Caron et al., 2017; Danysz et al., 2018; Ghorbani et al., 2012; Yoshida et al., 1994). Two to three weeks of daily injection at a dose of $1 \mathrm{mg} / \mathrm{kg}$ per day are necessary to improve metabolic disorders (Burkey et al., 2000; de Souza et al., 1997; Kim et al., 2006; Kumar et al., 2015; 
Labbé et al., 2016). Thus, mice were injected i.p. every day for a month with a weight-adjusted dose of $\mathrm{CL}-316,243(1 \mathrm{mg} / \mathrm{kg}$ ) or an equivalent volume of saline (the vehicle) at the same hour of the day (4 p.m.) from 15 to 16 months of age (Fig. 1A). Mice were weighed every day before each i.p. injection. Mice were sacrificed the morning after the last injection.

\section{Body temperature measurement and analysis}

Telemetric probes (Anipill, Caen, France) were used to record body temperature of the animals every hour during the one-month experiment without manipulation. Probes were implanted in the intraperitoneal cavity under isoflurane anesthesia a week before the beginning of the treatment to allow recovery from the surgery (Fig. 1A). Heat pads were used throughout the procedure to avoid hypothermia. The time under anesthesia was similar between mice and lasted approximately 10 minutes. Then, the animals were kept under heat pads during the waking period. Body temperature was analyzed during the two first weeks of treatment, before animals underwent glucose tolerance and behavioral tests, to avoid resulting interference in circadian rhythms.

In order to assess potential phase advances or delays and to visualize endogenous rhythmicity and regularity of the mice circadian clock, Clocklab software (Actimetrics Inc., Evanston, Illinois, USA) provided the further information: individual mean daily offsets in hours (determined as the time of the first six successive bins when temperature was lower than the mean diurnal temperature), offset standard deviation in hours and mean duration of a total temperature cycle in hours. We performed our analyses based on daily offsets (the end of the active period of the mice) because daily injections of the drug were performed only three hours before the lights turned off, thus influencing the onsets (the beginning of the active period). Other following parameters were calculated for each individual: mean body temperature in ${ }^{\circ} \mathrm{C}$ during the dark (from 7 p.m. to 7 a.m.) and light phase (from 7 a.m. to 7 p.m.) and mean amplitude of temperature $\left(\mathrm{T}^{\circ} \mathrm{max}-\mathrm{T}^{\circ} \mathrm{min}\right)$ in ${ }^{\circ} \mathrm{C}$ during the dark and light phase.

\section{Glucose tolerance test, fasting blood glucose, leptin and insulin}

Glucose tolerance test (GTT) was performed at the end of the third week of treatment (Fig. 1A) (Vandal et al., 2015). Mice were fasted for 6 hours (from 8 a.m. to 2 p.m.). Then, glucose was injected i.p. at 1 $\mathrm{g} / \mathrm{kg}$ and blood glucose was measured regularly during 2 hours with a glucometer (OneTouch UltraMini; LifeScan, Milpitas, CA) in a blood drop sampled from the saphenous vein. Leptin and insulin were assessed by ELISAs (Leptin Mouse ELISA kit, ab100718, Abcam; Mouse insulin ELISA, \#10-1247-01, 
Mercodia, Sweden) following manufacturer's instructions in plasma sampled in the saphenous vein after the 6-hour fasting during the GTT test.

\section{Behavioral tests}

Behavioral tests were performed during the fourth week of treatment with a recovery time of at least 24 hours between tests (Fig. 1A). The novel object recognition (NOR) test was also performed three weeks before the beginning of the treatment to obtain a baseline index ratio for each animal (see below). Mice were acclimated overnight to the testing room located next to the housing room.

Locomotor activity was assessed with the open field test (Dal-Pan et al., 2016). Mice were placed in a 40 $\mathrm{cm} \times 40 \mathrm{~cm}$ x $40 \mathrm{~cm}$ translucent Plexiglas box for an hour. Movements were tracked with photobeam breaks (San Diego Instruments). The total distance traveled (voluntary horizontal movement) and the average speed were compared between groups.

Anxiety behavior was evaluated with the dark-light box test (Vandal et al., 2016). Mice were put in the center of the dark compartment with an opening to the light compartment. The time spent in the light compartment and the latency to do the first exploration (nose latency) of the light compartment were measured during a 5-minute trial.

Memory deficits were evaluated with the NOR test. That test detects behavioral deficits from 12 months in 3xTg-AD mice and is one of the less stressful behavioral test (Arsenault et al., 2011; Clinton et al., 2007; St-Amour et al., 2014; Vandal et al., 2016). It evaluates recognition memory and corresponds to episodic memory that is early affected in AD (Antunes and Biala, 2012; Leger et al., 2013; Wolf et al., 2016). Mice were first placed in a $29.2 \mathrm{~cm} \times 19 \mathrm{~cm} \times 12.7 \mathrm{~cm}$ cage with two identical objects for 5 minutes during the acquisition phase. After an hour in their housing cage, mice returned in the testing cage containing a familiar and a novel object for the test phase. Recognition index (RI) corresponds to the time spent exploring the novel object divided by the total time of exploration during the test phase multiplied by 100 . A $50 \%$ RI corresponds to an equal exploration between the novel and the familiar object. Mice exploring less than 6 seconds each object during the acquisition phase or less than 4 seconds during the test phase were excluded from the RI analysis. Mice were assigned to the treated or the control group at 15 months of age with caution to homogenize memory performance (baseline RI) between groups at the beginning of the experiment.

\section{Tissue preparation for postmortem analysis}


Intracardiac blood sampled just before intracardiac perfusion in a heparinized tub was centrifuged at $3000 \mathrm{rpm}$ for 5 minutes, and resulting plasma kept frozen at $-80^{\circ} \mathrm{C}$ until analysis. The first hemisphere and interscapular BAT were rapidly dissected and frozen at $-80{ }^{\circ} \mathrm{C}$ until processing. The second hemisphere was either fixed in $4 \%$ paraformaldehyde for 48 hours and transferred in a $20 \%$ sucrose solution until sectioning (3-4 mice per group) or frozen and kept at $-80^{\circ} \mathrm{C}$.

\section{Protein extractions}

For the hippocampus, frozen samples were homogenized in 8 volumes of a lysis buffer $(150 \mathrm{mM} \mathrm{NaCl}$, $10 \mathrm{mM} \mathrm{NaH}{ }_{2} \mathrm{PO}_{4}, 0.5 \%$ sodium deoxycholate, $0.5 \%$ sodium dodecyl sulfate, $1 \%$ Triton $\mathrm{X}-100$ ) containing a cocktail of protease and phosphatase inhibitors (Bimake, Houston, TX), sonicated ( $3 \times 45 \mathrm{~s}$ in a Sonic Dismembrator apparatus, Thermo Fisher Scientific, Waltham, MA) and centrifuged $(100,000 \mathrm{~g}, 20 \mathrm{~min}$, $4^{\circ} \mathrm{C}$ ), resulting in a detergent-soluble fraction (cytosolic, extracellular and membrane-bound proteins). The remaining pellets from ultracentrifugation were resuspended in formic acid, resulting in a detergent-insoluble fraction (insoluble proteins fraction). The resultant suspension was sonicated and centrifuged $\left(13,000 \mathrm{~g}, 20 \mathrm{~min}, 4^{\circ} \mathrm{C}\right)$, acid formic was evaporated and proteins were either solubilized in Laemmli's buffer for Western blot or in a $5 \mathrm{M}$ guanidium solution in Tris- $\mathrm{HCl} 50 \mathrm{mM}$ for $\mathrm{A} \beta$ peptides ELISAs as previously described (Tremblay et al., 2017). Proteins from the BAT were extracted in the lysis buffer only. Protein concentrations were evaluated with a bicinchoninic acid assay (BCA, Pierce, Rockford, IL, USA).

\section{Western immunoblotting}

$15 \mu \mathrm{g}$ and $10 \mu \mathrm{g}$ of proteins of hippocampus and BAT homogenates, respectively, were loaded and separated by SDS-PAGE, as previously described (Vandal et al., 2014). The list of antibodies used in this study is available in Table S2. Homogenates were all run on the same gel for each experiment.

\section{$A \beta 40$ and $A \beta 42$ peptides quantification}

$A \beta$ peptides were quantified in protein extracts from the hippocampus. $A \beta 40$ and $A \beta 42$ were measured in detergent-soluble and detergent-insoluble fractions using a human $\beta$-amyloid ELISA (Wako, Osaka, Japan) according to the manufacturer's instructions. Plates were read at $450 \mathrm{~nm}$ using a Synergy ${ }^{\mathrm{TM}} \mathrm{HT}$ multi-detection microplate reader (Biotek, Winooski, VT).

\section{High-performance liquid chromatography (HPLC)}


HPLC was used to measure the level of norepinephrine in BAT. An average of $10 \mathrm{mg}$ of BAT was homogenized in perchloric acid $(0.1 \mathrm{~N})$ and centrifuged 10 minutes at $4{ }^{\circ} \mathrm{C}$ at $13000 \mathrm{rpm} .5 \mu \mathrm{L}$ of the supernatant was injected in the HPLC with electrochemical detection (Water 717 plus Autosampler automatic injector, Waters 1525 Binary Pump) as previously described (Bousquet et al., 2011).

\section{Statistical analysis}

Data are represented as means \pm standard error of the mean (SEM). Statistical analysis and the number of samples per group are specified in each figure and legend. Bartlett's tests were used to rule out the inequality of variances between the groups. Two-way ANOVA (two independent variables: genotype and treatment) was used in case of equal variances. Repeated measures two-way ANOVA was executed to compare recurrent measurements in same animals. Tukey's test was used for post-hoc analysis. In case of unequal variances, a Kruskal-Wallis followed by a Dunn's post-hoc test was performed. An unpaired Student's t-test was performed when only two groups were compared, with a Welch correction in case of unequal variances. Paired t-test was executed for the before-and-after on comparison on the same animals. One sample t-test was used to compare means to a theoretical value (for the NOR test). Correlations between variables were investigated using linear regression analyses. All statistical analyses were performed with Prism 7 (GraphPad Software Inc., San Diego, CA, USA) or JMP (version 13.2.0; SAS Institute Inc., Cary, IL, USA) software and statistical significance was set at $p<0.05$. 


\section{RESULTS}

\section{1. $\beta 3 A R$ stimulation improves peripheral glucose metabolism in old mice.}

NonTg and 3xTg-AD mice received CL-316,243 or saline i.p. at a dose of $1 \mathrm{mg} / \mathrm{kg}$ every day for a month from 15 to 16 months of age (Fig. 1A). To verify whether CL-316,243 affects energy balance, mice were weighed every day before each i.p. injection and food consumption was evaluated three weeks before the beginning of the experiment and then, every four days during the one-month treatment. First, we found that CL-316,243 injections induced persisting weight loss in both NonTg and 3xTg-AD mice (Fig. $1 B, C)$. At the beginning of the experiment, food consumption recorded in the previous 21 days was higher in 3xTg-AD compared to NonTg mice (average of $4.7 \mathrm{~g} /$ day/mice for 3xTg-AD versus 3.9 g/day/mice for NonTg mice; unpaired t-test with Welch's correction: $p=0.0105)$ (Fig. 1D), consistent with lower plasmatic leptin in fasted 3xTg-AD mice compared to NonTg (Fig. 1F). Over the one-month period, B3AR stimulation increased food consumption in NonTg mice up to levels of transgenic mice (Fig. 1D,E). The GTT revealed that CL-316,243-treated mice displayed a stronger control over glucose levels compared to control, independently of the genotype (Fig. 1G,H). Fasting blood glucose and insulin were also lower following three weeks of CL-316,243 administration (Fig. 11,J). However, levels of plasmatic triglycerides were unchanged (Fig. 1K). Overall, our data indicate that $\beta 3 A R$ stimulation led to an improved pattern of metabolic determinants in the periphery in both NonTg and 3xTg-AD mice at 15-16 months of age.

\section{B3AR stimulation increases brown adipose tissue thermogenesis.}

A telemetric probe implanted a week before the beginning of the treatment revealed daily variation in body temperature corresponding to the sleep-wake cycles of mice (Fig. 2A, Fig. S1). The mean amplitude of body temperature was larger by $0.4^{\circ} \mathrm{C}$ in 3xTg-AD than in NonTg mice during both 12-h light and 12-h dark phases (Fig. 2A-C, Fig. S1D), in agreement with thermoregulation defects previously reported in the same model (Vandal et al., 2016). CL-316,243 treatment further increased the amplitude of body temperature during the light phase (from 7 a.m. to 7 p.m.) compared to saline injections (Fig. 2B), corresponding to the injection time, but not during the dark phase (Fig. 2C). This is consistent with higher area under curve of body temperature measured after the first injection of CL-316,243 (between 4 p.m. and 12 p.m.) (Fig. 2D,E).

Since CL-316,243 is well known to improve thermogenesis capacity in mice (Labbé et al., 2016; Poher et al., 2015; Xiao et al., 2015), we then verified whether it was also effective in old NonTg and 3xTg-AD 
mice. First, interscapular BAT weight was slightly lower in 3xTg-AD compared to NonTg mice, but was not affected by the treatment (Fig. 2F). However, CL-316,243 administration increased the level of UCP1 protein in the BAT of both genotypes (Fig. 2G) but did not affect the norepinephrine content (Fig. S1E). Further confirming that $C L-316,243$ interacted with $\beta 3 A R$, levels of $\beta 3 A R$ in BAT were significantly decreased only in NonTg treated mice, despite a tendency also in 3xTg-AD mice (Fig. $2 \mathrm{H}$ ). We then measured complexes I to $\mathrm{V}$ of the mitochondrial oxidative phosphorylation complex that are involved in heat production during thermogenesis in BAT (Nam and Cooper, 2015). Complex I was increased in NonTg and 3xTg-AD mice following CL-316,243 administration (Fig. 2I,J). CL-316,243 increased complex IV in NonTg, but not in 3xTg-AD mice, whereas complexes II, III and V remained unchanged in both models. Altogether, our data show that the $\beta 3 A R$ agonist administration improves BAT thermogenesis and heat production in 16-month-old mice.

\section{3. $\beta 3 A R$ stimulation reverses memory deficits in 16-month-old 3xTg-AD mice.}

To determine whether CL-316,243 treatment exerted cognitive benefits in the 3xTg-AD mouse, recognition memory was evaluated with the NOR test 3 weeks before the beginning of the treatment (baseline, 14-month-old) and after the one-month treatment (final, 16-month-old) (Fig. 1A). The NOR test was selected because of its sensitivity and reliability to detect memory deficits in the 3xTg-AD mice at 12 months and older (Fig. 3A) (Arsenault et al., 2011; Clinton et al., 2007; Vandal et al., 2016). Comparing RI before (14 months) and after (16 months) the treatment revealed that one-month treatment with CL-316,243 increased by $19 \%$ the ability to recognize the new object in 3xTg-AD mice (paired t-test: $p=0.0041$ ), while the change in RI was not significantly different in NonTg or salineinjected 3xTg-AD mice (Fig. 3B,C). CL-316,243 from 15 to 16 months improved memory recognition in 3xTg-AD mice ( $R \mathrm{I}=65 \%$ in $C L-316,243$-injected mice, one sample t-test versus 50\%: $p=0.0013$ ), but not in NonTg mice (Fig. 3D). The improved RI in 3xTg-AD treated mice was confirmed by the higher time spent on the novel $(\mathrm{N})$ versus the familial $(\mathrm{O})$ object (Fig. 3E). These differences were not explained by changes in exploratory behavior, as the mean duration of exploration was similar between groups (Fig. 3F). Finally, the percent change in RI before and after the treatment was positively correlated with UCP1 levels in BAT in 3xTg-AD $\left(r^{2}=0.37\right)$ but not in NonTg mice, suggesting a link between improved thermogenesis and memory (Fig. 3G).

We then verified that locomotor activity was not affected by CL-316,243 injections, as showed by comparable distance traveled and average speed of the mice during the open field test (Fig. $3 \mathrm{H}-\mathrm{J}$ ). 
Nonetheless, 2-way ANOVA revealed that 3xTg-AD mice displayed a higher average speed during the one-hour session compared to NonTg mice (Fig. 3J).

Anxiety is frequently observed in AD patients and is replicated in 3xTg-AD mice (Hebda-Bauer et al., 2013; St-Amour et al., 2014; Vandal et al., 2016). The time spent in the illuminated compartment was not significantly different between groups in the present cohorts of animals (Fig. 3L). However, 3xTg-AD mice delayed their first exploration in the light chamber, as measured by the latency of the first nose entry in the light compartment (nose poke latency) (Fig. 3M), corroborating an anxiety-like behavior in this model.

Overall, one-month administration of CL-316,243 improved recognition memory assessed at 16 months in 3xTg-AD mice, without affecting locomotion nor anxiety-like behavior.

\section{4. $\beta 3 A R$ stimulation reduces insoluble $A \beta 42 / A \beta 40$ ratio in the hippocampus of $3 \times T g-A D$ mice.}

The main neuropathological markers of $A D$, amyloid plaques and tau pathology (Iqbal et al., 2016; Selkoe and Hardy, 2016), progressively develop in the brain of 3xTg-AD mice (Belfiore et al., 2018; Oddo et al., 2003; Vandal et al., 2015). Although total $A \beta 42$ and $A \beta 40$ peptides in either soluble or insoluble fractions remained unchanged by the treatment in the hippocampus (Fig. 4A-D), we observed a $27 \%$ decrease in insoluble $A \beta 42 / A \beta 40$ ratio in CL-316,243-treated mice compared to saline-injected 3xTg-AD mice (Fig. 4E). We subsequently assessed the effect of the $\beta 3 A R$ agonist on proteins implicated in the production (beta-secretase 1 (BACE-1), amyloid precursor protein (APP), APP C-terminal, sAPP $\alpha$ ) and clearance or degradation (low density lipoprotein receptor related protein 1 (LRP1), receptor of advanced glycation end products (RAGE), insulin degrading enzyme (IDE), X11 $\alpha$ ) of A $\beta$ peptides (Table S1) (Donahue et al., 2006; Farris et al., 2003; Selkoe and Hardy, 2016). Levels of BACE-1, IDE, LRP1 and RAGE in the hippocampus did not differ between groups, whereas those of X11 $\alpha$ were lower in 3XTg-AD mice compared to NonTg mice (Table S1) as observed in the brain of AD individuals (Tremblay et al., 2017).

We then assessed the level of phosphorylated and total tau protein in the detergent-soluble (cytosolic and membrane proteins) and detergent-insoluble (aggregated proteins) fractions of hippocampus homogenates by Western Blot. We did not find any significant effect of CL-316,243 (Fig. 5) but confirmed that the 3xTg-AD mice display higher total and hyperphosphorylated tau proteins compared to NonTg mice. Main kinases involved in tau phosphorylation (glycogen synthase kinase $3 \beta$ (GSK3 $\beta$ ) and protein kinase B known as AKT) were also unchanged (Table S1). 
Synaptic deficits are one of the earliest markers of AD, correlating with symptoms (Arendt, 2009; Tremblay et al., 2017). The levels of synaptic proteins were not modified by the treatment (Table S1). However, drebrin protein was decreased specifically in 3xTg-AD mice (Two-way ANOVA, effect of genotype: $p=0.0045$ ), as previously showed in the brain of AD subjects (Calon et al., 2004; Julien et al., 2008).

Since glucose transporters and uptake are decreased in AD (An et al., 2018; Kalaria and Harik, 1989; Y. Liu et al., 2008; Simpson et al., 1994), we assessed glucose transporter 1 (GLUT1) levels in the hippocampus of the mice. While we did not detect any effect of the CL-316,243 treatment, GLUT1 levels were decreased in the hippocampus of 3xTg-AD mice compared to NonTg mice, at both the endothelial (50 kDa) and astrocytic (45 kDa) isoforms (Table S1), corroborating defects in glucose uptake, changes in blood-brain barrier transporters and decreased cerebral vascular volume observed in this mouse model of AD (Bourasset et al., 2009; T. M. Do et al., 2014; 2016; Nicholson et al., 2010). 


\section{DISCUSSION}

The present study aimed at investigating whether $\beta 3 A R$ agonist administration induces BAT thermogenesis and exerts an effect on cognitive behavior and $A D$ neuropathology in a mouse model of the disease. The 3xTg-AD mice was selected to test the effect of $\beta 3 A R$ stimulation in $A D$ because this model displays age-dependent metabolic and thermoregulatory deficits and was shown to respond to thermoneutrality and BAT stimulation induced by repeated cold exposure (Knight et al., 2013; Tournissac et al., 2019; Vandal et al., 2016). This led to the hypothesis that pharmacological BAT stimulation could exert benefit on AD-like behavior and neuropathology. We thus treated 15-month-old NonTg and 3xTg-AD mice with the selective $33 A R$ agonist CL-316,243 or saline for a month. We found that chronic administration of the agonist stimulated BAT thermogenesis and improved glucose homeostasis. Enhanced thermogenesis was associated with improved recognition memory in 16 months $3 x \operatorname{Tg}-A D$ mice and reduced insoluble $A \beta 42 / A \beta 40$ ratio in the hippocampus, while tau pathology remained unaffected.

\section{B3AR agonist: a two in one strategy to target both metabolic and thermoregulatory defects.}

The most well-known characteristic of CL-316,243 is to improve metabolic disorders through enhanced BAT activity (Burkey et al., 2000; de Souza et al., 1997; Kim et al., 2006; Kumar et al., 2015; Labbé et al., 2016) (Cypess et al., 2015; Loh et al., 2018). Whether this effect is maintained with age remains unknown. UCP1 and NADH dehydrogenase 1 beta subcomplex subunit 8 (NDUFB8 or Complex I) are both recognized markers of BAT activation (Nam and Cooper, 2015). Higher levels of UCP1 and Complex I in the BAT detected here indicate a sustained effect of CL-316,243 on BAT thermogenesis after a onemonth chronic treatment in old mice. This is consistent with strong previous evidence that $\beta 3 A R$ stimulation leads to increased thermogenic activity of BAT in young mice (Labbé et al., 2016; Poher et al., 2015; Xiao et al., 2015) and humans as well (Cypess et al., 2015; Loh et al., 2018). It also shows that chronic $\beta 3 A R$ administration does not induce significant receptor desensitization, despite decreased levels of BAT $\beta 3 A R$ following treatment, in agreement with previous works (Nedergaard and Cannon, 2013). Overall, our data now confirms that $\beta 3 A R$-induced thermogenesis is still effective in a 15-monthold mouse, following a one-month treatment with CL-316,243, regardless of the presence of $A D$ neuropathology.

In the present study, B3AR agonist induced weight loss in both NonTg and 3xTg-AD mice. Food consumption was higher in 3xTg-AD compared to NonTg mice, an observation previously reported in this 
model (Adebakin et al., 2012; K. Do et al., 2018), and CL-316,243 increased food intake in NonTg mice. These data are consistent with increased energetic expenditure compensated with higher calorie intake following $\beta 3$ AR stimulation (Gavrilova et al., 2000; Xiao et al., 2015). We previously showed that female 3xTg-AD mice display age-dependent glucose intolerance starting from 12 months (Vandal et al., 2015). While the difference in glucose tolerance between NonTg and 3xTg-AD mice was not frank in the present work considering that only males were used, fasting blood glucose in 3xTg-AD was higher than in NonTg mice. It is noteworthy that the CL-316,243 improved peripheral glucose metabolism and fasted insulin in 16-month-old mice of both genotypes, suggesting an effect independent of $A D$ neuropathology. Of note, the improvement was observed in mice fed with a diet not expected to induce metabolic defects, suggesting benefits even in non-diabetic animals. This is in line with a previous study showing improved glucose metabolism with CL-316,243 administration even in mice displaying a normal response to glucose (Xiao et al., 2015).

Using hourly telemetric recordings of body temperature, we noted that 3xTg-AD mice displayed wider amplitudes of body temperature throughout the day compared to NonTg mice, corroborating previous findings showing that $A D$ neuropathology impacts thermoregulation (Vandal et al., 2016). On the other hand, $\beta 3 A R$ agonist increased amplitude of body temperature during the light phase, corresponding to the period of drug administration, but not during the dark phase. The wider amplitude in body temperature is consistent with higher body temperature after CL-316,243 injection, as shown by the temperature recorded few hours after the first i.p. injection and a previous work (Szentirmai and Kapás, 2017). However, we did not observed chronic hyperthermia, which would have been a major side effect of $\beta 3 A R$ agonists, perhaps compromising potential translation to clinical use.

\section{2. $\beta 3 A R$ stimulation reverses memory deficits in old 3XTg-AD mice.}

An important result of our study is the reversal of recognition memory deficit induced by $\beta 3 A R$ stimulation in 16-month-old 3xTg-AD mice. Indeed, we observed a 19\% increase of RI between baseline (14 months) and post-treatment evaluation (16 months). These results were not explained by changes in exploratory behavior or locomotor activity. The RI of NonTg mice following treatment did not reach statistical significance perhaps due to lower statistical power $(n=5)$, but was significantly different from $50 \%$ in saline-injected mice. Nevertheless, the data also suggest that $\beta 3 A R$-induced improvement in memory was specific to $3 x T g-A D$ mice, possibly through an effect related to AD neuropathology. The randomized-start design ensured that all animals were similar before undergoing saline or CL-316,243 treatment. One study also found memory improvement following CL-316,243 administration in $A \beta$ - 
injected chicks (Gibbs et al., 2010), but no previous report in mice was found in the literature. Thus, our results are consistent with a disease-modifying effect of $\beta 3 A R$ stimulation in the 3xTg-AD mice.

Since metabolic disorders also alter cognitive function and lead to memory defects (Abbondante et al., 2014; Gunstad et al., 2010; Rajasekar et al., 2017; Takeda et al., 2010; Tong et al., 2019), improved peripheral metabolism could be involved in better recognition memory in 3xTg-AD mice. However, it is not excluded that CL-316,243 has a direct effect in the CNS. Indeed, $\beta 3 A R$ are present in various regions of the brain, although to a much lower extent compared to the BAT (Evans et al., 1996; Summers et al., 1995), but their physiological roles in the central nervous system (CNS) are not known. While it has been shown that CL-316,243 increases sleep duration in mice (Szentirmai and Kapás, 2017) and reduces A $\beta$ induced long-term memory deficits in chicks (Gibbs et al., 2010), the behavioral effects of $\beta 3 A R$ agonists has not been the subject of intense investigation. Nonetheless, another $\beta 3 A R$ agonist, SR856611A (Amibegron ${ }^{\circledR}$ ), has been shown to improve anxiety and depressive-like symptoms in rodents, as evaluated by the forced swim test and the elevated plus maze (Consoli et al., 2007; Stemmelin et al., 2008; Tamburella et al., 2010), and has been the subject of phase III clinical trial for depression (NCT00252330). In the present work, we did not detect changes in anxiety-like behavior with the darklight box emergence test following CL-316,243 administration. What stand up from our data is that enhanced UCP1 levels in BAT were correlated with higher improvement in RI in 3xTg-AD mice, supporting the idea that higher BAT thermogenesis induced by $\beta 3 A R$ stimulation is involved in improved memory performance.

\section{3. $\beta 3 A R$ stimulation decreases insoluble $A \beta 42 / A \beta 40$ ratio but has no effect on tau phosphorylation in the hippocampus of 3xTg-AD mice.}

The 3xTg-AD model allowed us to probe whether the effect of $C L-316,243$ are related to changes in $A D$ neuropathology. Despite no change in total tau or $A \beta$ burden, a $27 \%$ decrease in insoluble $A \beta 42 / A \beta 40$ ratio was observed in the hippocampus of old 3xTg-AD mice following CL-316,243 injections. This observation is important because $A \beta 42 / A \beta 40$ ratio in the brain has been consistently associated with higher risk of developing $A D$, at least in genetic cases. Indeed, the $A \beta 42 / A \beta 40$ ratio is increased in familial forms of $A D$ and is inversely correlated with the age of onset of the disease (Kumar-Singh et al., 2006; Tanzi, 2012). Decreased $A \beta 42 / A \beta 40$ ratio suggests a shift in APP cleavage from $A \beta 42$ to $A \beta 40$, which is less prone to aggregation than $A \beta 42$. Importantly, increased $A \beta 42 / A \beta 40$ ratio precedes amyloid plaques formation in the Tg2576 mouse model of AD (Jacobsen et al., 2006). More recent work using 
induced pluripotent stem cells (iPSC) corroborates this view, indicating that APP or presenilin 1 (PSEN1) mutations, the more likely to cause familial $A D$, also leads to higher $A \beta 42 / A \beta 40$ ratio (Arber et al., 2019). The absence of changes on the phosphorylation status of tau following CL-316,243 administration could be interpreted as surprising. Since tau phosphorylation has been repeatedly shown to follow body temperature modulation (Arendt et al., 2003; Planel et al., 2007; Stieler et al., 2011), we could have expected a protective effect of $\beta 3 A R$ stimulation. For example, we recently showed that improved BAT thermogenesis through repeated cold exposure protects old 3xTg-AD mice from cold-induced tau phosphorylation (Tournissac et al., 2019). However, the present study design did not fully explore the hypothesis that $\beta 3 A R$ stimulation impacts tau phosphorylation, because the animals were kept at room temperature and not exposed to any frank thermoregulatory challenge (i.e. acute 24-h exposure to cold). Thus, because it has not been directly tested in the present study, it remains possible that pharmacological $\beta 3$ AR stimulation also confers protection against cold-induced tau phosphorylation.

\section{Conclusion: potential translation to clinic.}

The present work aimed to determine whether $\beta 3 A R$ agonists exert positive effects on AD-relevant endpoints in an animal model of tau and $A \beta$ neuropathology, thereby providing arguments for drug repurposing in $A D$. This class of drugs is actively being tested in clinical studies for metabolic diseases and CL-316,243 has been previously investigated in humans as well (Weyer et al., 1998). As an example, mirabegron (Myrbetriq ${ }^{\circledR}$ ) has been approved by the Food and Drug Administration for the treatment of overactive bladder (Chapple et al., 2014b; Cypess et al., 2015), and large randomized controlled trials have confirmed its safety and tolerability profiles (Chapple and Siddiqui, 2017). Thus, the potential translation to clinical use of this class of drugs in AD is high. Nonetheless, it has to be noted that in humans, potential side effects of $\beta 3 A R$ agonists include cardiovascular dysfunction induced by nonspecific activation of $\beta 1$ and $\beta 2$ adrenergic receptors. Indeed, one administration of mirabegron at a dose of $\mathbf{2 0 0} \mathrm{mg}$ (fourth times the clinical dose) enhances BAT activity in adults, but also induced cardiac arrhythmia in a few cases (Cypess et al., 2015). While the clinical dose of $50 \mathrm{mg}$ does not seem to be efficient to acutely stimulate BAT (Baskin et al., 2018), a recent study showed that $100 \mathrm{mg}$ of mirabegron enhances thermogenesis without any cardiovascular side effects in adults (Loh et al., 2018). Yet, longterm studies investigating chronic effect of $\beta 3 A R$ agonists in BAT thermogenesis in old volunteers are needed.

Altogether, our results in a mouse model of $A D$ demonstrate for the first time that $\beta 3 A R$ agonists are potent tools to reverse memory deficits and insoluble $A \beta 42 / A \beta 40$ ratio in the hippocampus. It is the first 
study to our knowledge to investigate the potential of this class of drugs in AD neuropathology and behavior.

\section{Declarations of interest}

The authors have no conflicts of interest to disclose.

\section{AUTHOR CONTRIBUTIONS}

M.T. designed the study, performed animal experiments, drug administration, behavior and metabolic evaluations, protein extractions, western blots, immunohistochemistry, HPLC, completed the statistical analysis, interpretation of the data, and wrote the manuscript. T.V. contributed to animal experiments and western blots. N.V. performed western blots and contributed to protein extractions. C.H. and F.P. performed chronobiology analysis on body temperature and reviewed the manuscript. C.T. performed $A \beta$ quantification. K.M. contributed to norepinephrine extraction and measurement. E.P. provided expertise for the tau analysis and reviewed the manuscript. F.C. secured funding, contributed to the experimental design, and wrote the manuscript. F.C. is the guarantor of this work and, as such, had full access to all the data in the study and takes responsibility for the integrity of the data and the accuracy of the data analysis.

\section{ACKNOWLEDGMENTS}

M.T. was funded by a scholarship from the Alzheimer Society of Canada. This study was made possible by funding from the Alzheimer Society of Canada (\#15-02 and \#20-01), the Canadian Institutes of Health Research (MOP 102532), the Quebec Network for Research on Aging and the Canadian Foundation for

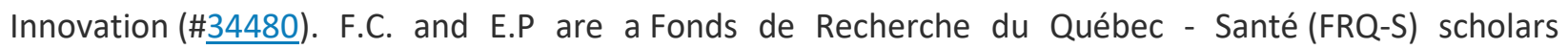
(\#253895, \#26936, and \#252178). The authors are grateful to Patrick Caron and Chantal Guillemette for technical support and to Isabelle Guisle for comments on the manuscript. The authors thank the animal facility technicians Sonia Francoeur, Stéphanie Bernard and France Duclos for their help during the animal experiment. 


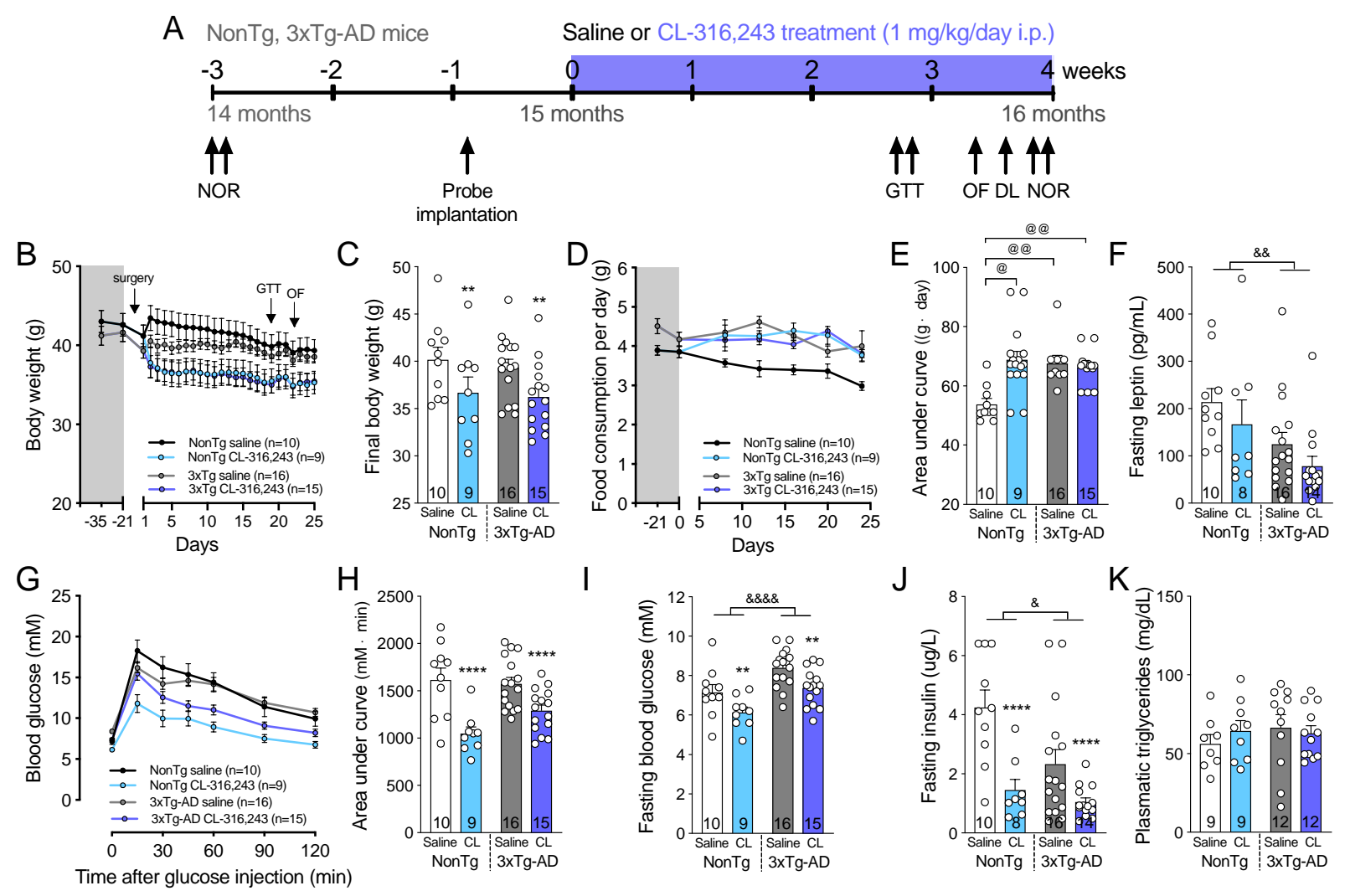

Figure 1. B3AR stimulation improves peripheral glucose metabolism in NonTg and 3xTg-AD mice.

A: Schematic description of the experimentation. B: Body weight before and during the one-month experiment and C: at the end of the experiment. D: Food consumed per day per mice three weeks before and over the one-month treatment and $\mathrm{E}$ : area under curve of food consumption over the onemonth treatment. F: Leptin measured in plasma of fasted mice. G: GTT performed after 3 weeks of experiment and $\mathrm{H}$ : area under curve of the GTT. I: Fasting blood glucose and J: plasmatic insulin measured during the GTT. I: Triglycerides measured in the plasma sampled at the end of the experiment.

Data are represented as mean \pm SEM (n/group indicated in graphics). Statistics: Two-way ANOVA, effect of treatment: ${ }^{* *} p<0.01 ;{ }^{* * * *} p<0.0001$; effect of genotype: ${ }^{\&} p<0.05 ;{ }^{\& \&} p<0.01 ;{ }^{\& \& \&} p<0.0001(C, F, H, I, J)$. Kruskal-Wallis, Dunn's post-hoc test: ${ }^{@} p<0.05 ;{ }^{@}{ }_{p}<0.01(E)$.

Abbreviations: 3xTg-AD: triple transgenic mice; DL: dark-light box test; GTT: glucose tolerance test; NonTg: non-transgenic mice; NOR: novel object recognition test; OF: open field. 

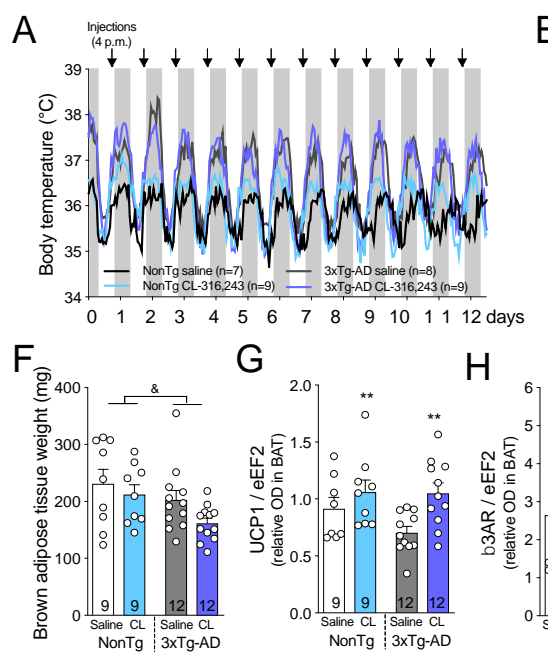
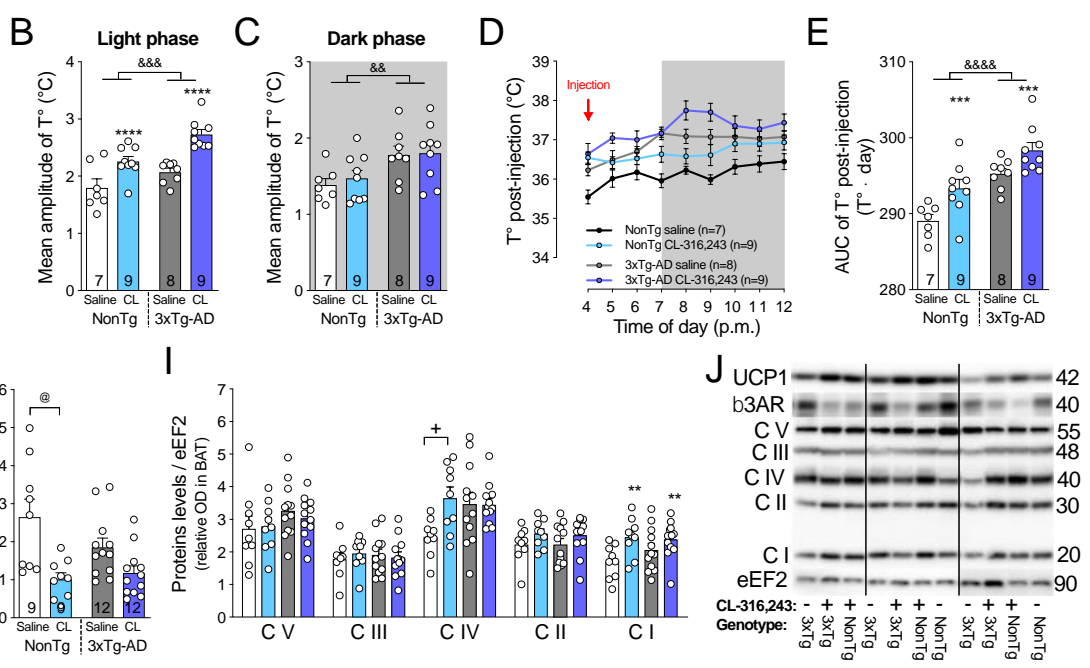

Figure 2. CL-316,243 treatment increases brown adipose tissue thermogenesis.

A: Graphical representation of body temperature recorded hourly by telemetric probe in the first two weeks of experiment (before glucose tolerance and behavioral tests). B: Mean amplitude of body temperature during the light (12-h, from 7 a.m.) and C: the dark phase (12-h, from 7 p.m.). D: Body temperature $\left(\mathrm{T}^{\circ}\right)$ and $\mathrm{E}$ : area under curve of the $\mathrm{T}^{\circ}$ after the first $\mathrm{CL}-316,243$ or saline i.p. injection. $\mathrm{F}$ : Interscapular BAT weights. Levels of G: UCP1, H: $\beta 3 A R$ and I: mitochondrial oxidative phosphorylation system on eEF2 proteins measured in BAT by Western Blot. J: Examples of Western Blots. Homogenates were all run on the same gel, but consecutive bands were not taken for all representative photo examples.

Data are represented as mean \pm SEM (n/group indicated in each column). Statistics: Two-way ANOVA, effect of treatment: ${ }^{* *} p<0.01 ;{ }^{* * *} p<0.001 ;{ }^{* * * *} p<0.0001$; effect of genotype: ${ }^{\&} p<0.05 ;{ }^{\& \&} p<0.01$; ${ }^{\& \& \&} p<0.001 ;{ }^{\& \& \&} p<0.0001(B, C, E-G, I)$; Tukey's post-hoc test: ${ }^{+} p<0.05$. Kruskal-Wallis (I), Dunn's post-hoc test: ${ }^{@} p<0.05(H)$.

Abbreviations: AUC: area under curve; 3xTg-AD: triple transgenic mice; $\beta 3 A R: \beta 3$ adrenergic receptor; BAT: brown adipose tissue; CV, CIII, CIV, CII, Cl: mitochondrial oxidative phosphorylation system complex V, III, IV, II, I; eEF2: eukaryotic elongation factor 2; NonTg: non-transgenic mice; OD: optical density; $\mathrm{T}^{\circ}$ : temperature; UCP1: uncoupling protein 1. 

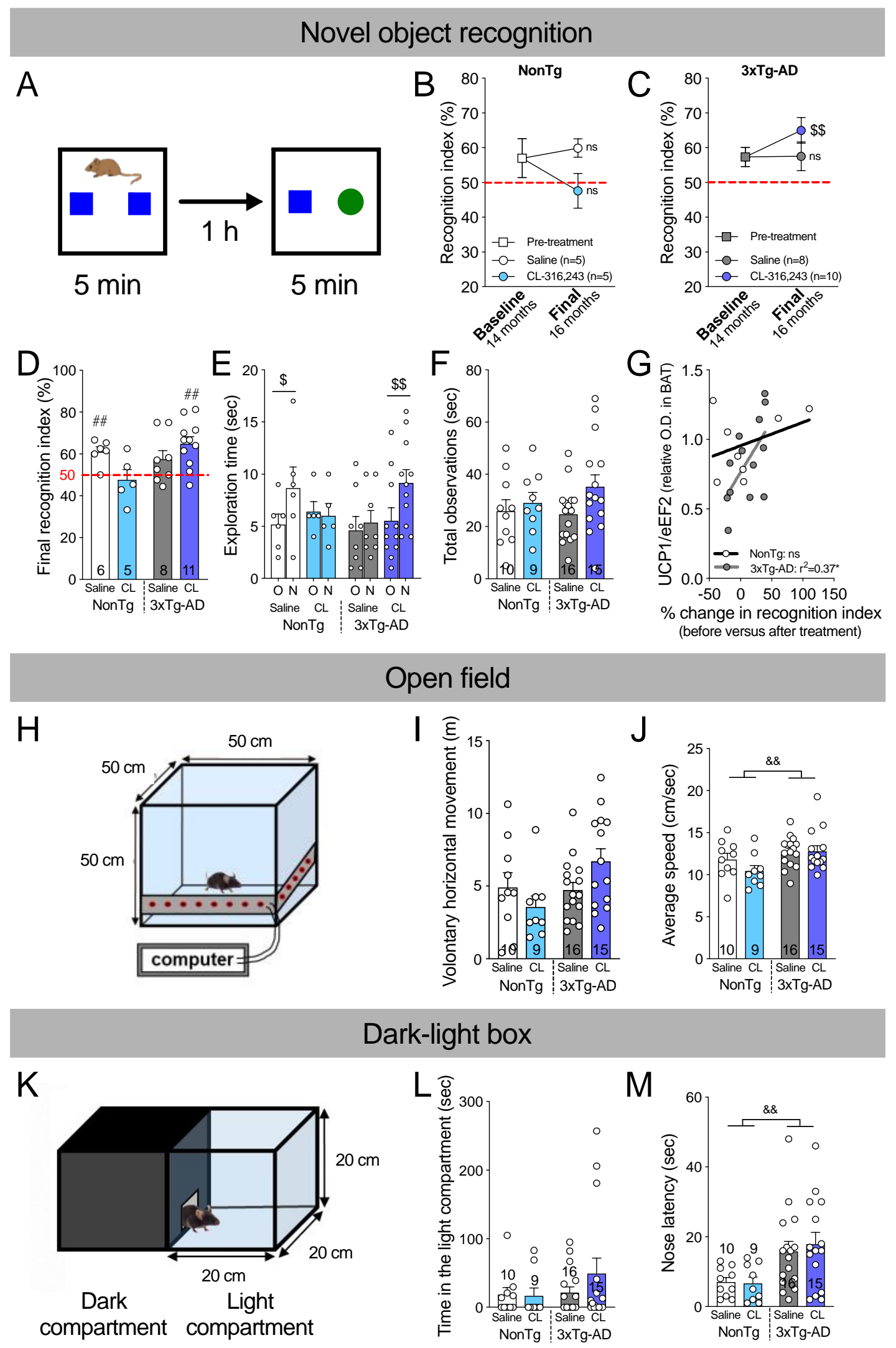

Figure 3. $\beta 3 A R$ stimulation reverses memory deficits in 16-month-old 3xTg-AD. 
A: Description of the novel object recognition test. Recognition indexes (RI) assessed before and after the treatment with CL-316,243 or saline in B: NonTg and C: 3xTg-AD mice. D: Final recognition index, E: time spent exploring the old $(\mathrm{O})$ and the novel $(\mathrm{N})$ object during the 5-minutes acquisition phase and $\mathrm{F}$ : total observations measured at the end of the experiment (final, 16-month-old mice). G: Correlation between \% change in recognition index before and after the treatment and UCP1 levels measured in BAT. H: Representation of the open field apparatus. I: Total distance traveled and J: average speed during the one-hour test. K: Representation of the dark-light box. L: Time spent in the light compartment and $\mathrm{M}$ : latency to do the first exploration in the light compartment.

Recognition index $=$ (time exploring the novel object / total exploration time) $x$ 100. Data are represented as mean \pm SEM ( $n$ /group indicated in graphics). Statistics: Paired t-test (Baseline versus final recognition index $(B, C)$; Old $(O)$ versus novel $(N)$ object $(E))$ : ${ }^{\$} p<0.05 ;{ }^{\$} p<0.01(B, C, E)$. One sample t-test versus 50\% (random chance): ${ }^{\#} p<0.01$ (D). Pearson $r$ correlation: ${ }^{*} p<0.05$ (G). Two-way ANOVA, effect of genotype: ${ }^{\& \&} \mathrm{p}<0.01(\mathrm{~J}, \mathrm{M})$.

Abbreviations: 3xTg-AD: triple transgenic mice; eEF2: eukaryotic elongation factor 2; O.D., optical density; NonTg: non-transgenic mice; UCP1: uncoupling protein 1.
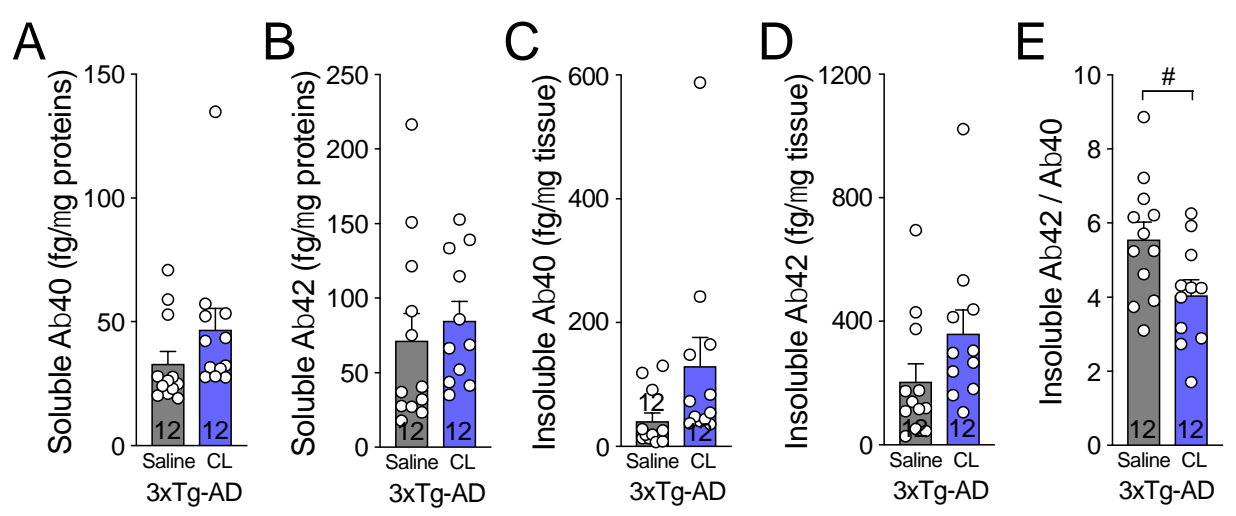

Figure 4. $\beta 3 A R$ stimulation reduces insoluble $A \beta 42 / A \beta 40$ ratio in the hippocampus of $3 \times T g-A D$ mice.

Human $A B 40$ and $A \beta 42$ peptides measured by ELISA in the $A, B$ : detergent-soluble and in the $C, D$ : detergent-insoluble fractions of hippocampus homogenates of 3xTg-AD mice, respectively. E: Ratio of insoluble $A \beta 42$ on $A \beta 40$ peptides in the hippocampus.

Data are represented as mean \pm SEM (n/group indicated in bars). Statistics: Unpaired Student t-test: \#p<0.05 (A-E).

Abbreviations: 3xTg-AD: triple transgenic mice; $A \beta$ : amyloid-beta; NonTg: non-transgenic mice. 


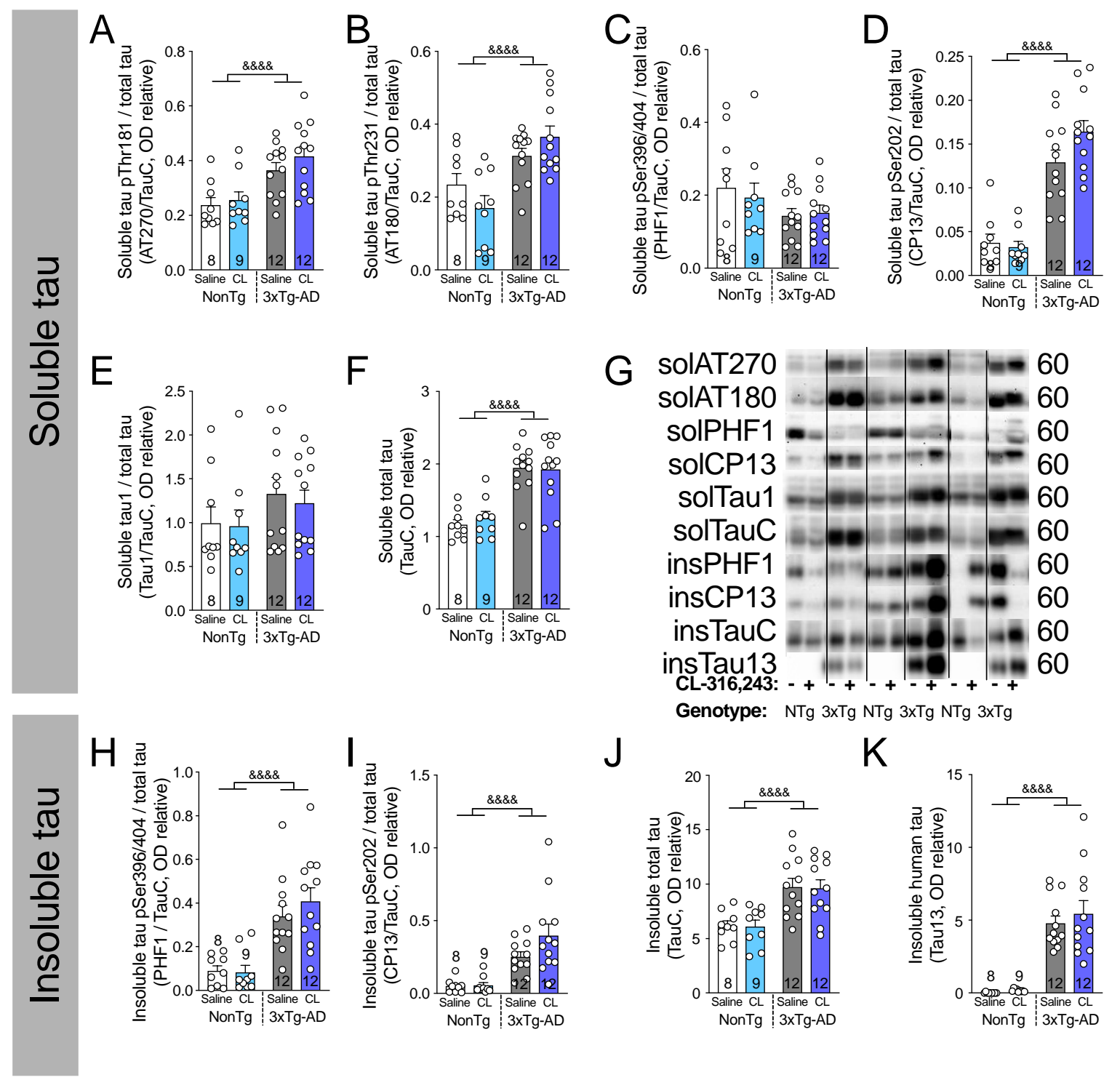

Figure 5. B3AR stimulation has no effect on tau phosphorylation in the hippocampus of 3xTg-AD mice.

Phosphorylated and total tau protein measured in A-F: detergent-soluble and $\mathrm{H}-\mathrm{K}$ : detergent-insoluble fractions of hippocampus homogenates of non-transgenic and 3xTg-AD mice. G: Examples of Western Blots. Homogenates were all run on the same gel, but consecutive bands were not taken for all representative photo examples and were cut-pasted to match the histogram order.

Data are represented as mean \pm SEM (n/group indicated in bars). Statistics: Two-way ANOVA, effect of genotype: ${ }^{\& \& \& \&} \mathrm{p}<0.0001(\mathrm{~A}-\mathrm{K})$.

Abbreviations: 3xTg-AD: triple transgenic mice; ins: insoluble; NonTg: non-transgenic mice; OD: optical density; sol: soluble. 


\section{REFERENCES}

Abbondante, S., Baglietto-Vargas, D., Rodriguez-Ortiz, C.J., Estrada-Hernandez, T., Medeiros, R., LaFerla, F.M., 2014. Genetic ablation of tau mitigates cognitive impairment induced by type 1 diabetes. The American Journal of Pathology 184, 819-826. doi:10.1016/j.ajpath.2013.11.021

Adebakin, A., Bradley, J., Gümüsgöz, S., Waters, E.J., Lawrence, C.B., 2012. Impaired satiation and increased feeding behaviour in the triple-transgenic Alzheimer's disease mouse model. PLoS ONE 7, e45179. doi:10.1371/journal.pone.0045179

An, Y., Varma, V.R., Varma, S., Casanova, R., Dammer, E., Pletnikova, O., Chia, C.W., Egan, J.M., Ferrucci, L., Troncoso, J., Levey, A.I., Lah, J., Seyfried, N.T., Legido-Quigley, C., O'Brien, R., Thambisetty, M., 2018. Evidence for brain glucose dysregulation in Alzheimer's disease. Alzheimers Dement 14, 318329. doi:10.1016/j.jalz.2017.09.011

Antunes, M., Biala, G., 2012. The novel object recognition memory: neurobiology, test procedure, and its modifications. Cogn Process 13, 93-110. doi:10.1007/s10339-011-0430-z

Arber, C., Toombs, J., Lovejoy, C., Ryan, N.S., Paterson, R.W., Willumsen, N., Gkanatsiou, E., Portelius, E., Blennow, K., Heslegrave, A., Schott, J.M., Hardy, J., Lashley, T., Fox, N.C., Zetterberg, H., Wray, S., 2019. Familial Alzheimer's disease patient-derived neurons reveal distinct mutation-specific effects on amyloid beta. Mol. Psychiatry 8, 595. doi:10.1038/s41380-019-0410-8

Arch, J.R.S., 2011. Challenges in $\beta(3)$-Adrenoceptor Agonist Drug Development. Ther Adv Endocrinol Metab 2, 59-64. doi:10.1177/2042018811398517

Arendt, T., 2009. Synaptic degeneration in Alzheimer's disease. Acta Neuropathol 118, 167-179. doi:10.1007/s00401-009-0536-x

Arendt, T., Stieler, J., Strijkstra, A.M., Hut, R.A., Rüdiger, J., Van der Zee, E.A., Harkany, T., Holzer, M., Härtig, W., 2003. Reversible paired helical filament-like phosphorylation of tau is an adaptive process associated with neuronal plasticity in hibernating animals. J Neurosci 23, 6972-6981.

Arnold, S.E., Arvanitakis, Z., Macauley-Rambach, S.L., Koenig, A.M., Wang, H.-Y., Ahima, R.S., Craft, S., Gandy, S., Buettner, C., Stoeckel, L.E., Holtzman, D.M., Nathan, D.M., 2018. Brain insulin resistance in type 2 diabetes and Alzheimer disease: concepts and conundrums. Nat Rev Neurol 14, 168-181. doi:10.1038/nrneurol.2017.185

Arsenault, D., Julien, C., Tremblay, C., Calon, F., 2011. DHA improves cognition and prevents dysfunction of entorhinal cortex neurons in 3xTg-AD mice. 6, e17397. doi:10.1371/journal.pone.0017397

Baskin, A.S., Linderman, J.D., Brychta, R.J., McGehee, S., Anflick-Chames, E., Cero, C., Johnson, J.W., O'Mara, A.E., Fletcher, L.A., Leitner, B.P., Duckworth, C.J., Huang, S., Cai, H., Garraffo, H.M., Millo, C.M., Dieckmann, W., Tolstikov, V., Chen, E.Y., Gao, F., Narain, N.R., Kiebish, M.A., Walter, P.J., Herscovitch, P., Chen, K.Y., Cypess, A.M., 2018. Regulation of Human Adipose Tissue Activation, Gallbladder Size, and Bile Acid Metabolism by a $\beta 3$-Adrenergic Receptor Agonist. Diabetes db180462. doi:10.2337/db18-0462

Belfiore, R., Rodin, A., Ferreira, E., Velazquez, R., Branca, C., Caccamo, A., Oddo, S., 2018. Temporal and regional progression of Alzheimer's disease-like pathology in 3xTg-AD mice. Aging Cell 12, e12873. doi:10.1111/acel.12873

Biessels, G.J., Staekenborg, S., Brunner, E., Brayne, C., Scheltens, P., 2006. Risk of dementia in diabetes mellitus: a systematic review. Lancet Neurol 5, 64-74. doi:10.1016/S1474-4422(05)70284-2

Bloom, J.D., Dutia, M.D., Johnson, B.D., Wissner, A., Burns, M.G., Largis, E.E., Dolan, J.A., Claus, T.H., 1992. Disodium (R,R)-5-[2-[[2-(3-chlorophenyl)-2-hydroxyethyl]-amino] propyl]-1,3-benzodioxole2,2-dicarboxylate ( $C L 316,243$ ). A potent beta-adrenergic agonist virtually specific for beta 3 receptors. A promising antidiabetic and antiobesity agent. J. Med. Chem. 35, 3081-3084.

Bories, C., Guitton, M.J., Julien, C., Tremblay, C., Vandal, M., Msaid, M., De Koninck, Y., Calon, F., 2012. Sex-dependent alterations in social behaviour and cortical synaptic activity coincide at different 
ages in a model of Alzheimer's disease. 7, e46111. doi:10.1371/journal.pone.0046111

Bourasset, F., Ouellet, M., Tremblay, C., Julien, C., Do, T.M., Oddo, S., LaFerla, F., Calon, F., 2009. Reduction of the cerebrovascular volume in a transgenic mouse model of Alzheimer's disease. Neuropharmacology 56, 808-813.

Bousquet, M., Gue, K., Emond, V., Julien, P., Kang, J.X., Cicchetti, F., Calon, F., 2011. Transgenic conversion of omega- 6 into omega-3 fatty acids in a mouse model of Parkinson's disease. J. Lipid Res. 52, 263-271. doi:10.1194/jlr.M011692

Burkey, B.F., Dong, M., Gagen, K., Eckhardt, M., Dragonas, N., Chen, W., Grosenstein, P., Argentieri, G., de Souza, C.J., 2000. Effects of pioglitazone on promoting energy storage, not expenditure, in brown adipose tissue of obese fa/fa Zucker rats: comparison to CL 316,243. Metabolism 49, 1301-1308. doi:10.1053/meta.2000.9524

Calon, F., Lim, G.P., Yang, F., Morihara, T., Teter, B., Ubeda, O., Rostaing, P., Triller, A., Salem, N., Ashe, K.H., Frautschy, S.A., Cole, G.M., 2004. Docosahexaenoic acid protects from dendritic pathology in an Alzheimer's disease mouse model. Neuron 43,633-645. doi:10.1016/j.neuron.2004.08.013

Cannon, B., Nedergaard, J., 2004. Brown adipose tissue: function and physiological significance. Physiol. Rev. 84, 277-359. doi:10.1152/physrev.00015.2003

Caron, A., Labbé, S.M., Carter, S., Roy, M.-C., Lecomte, R., Ricquier, D., Picard, F., Richard, D., 2017. Loss of UCP2 impairs cold-induced non-shivering thermogenesis by promoting a shift toward glucose utilization in brown adipose tissue. Biochimie 134, 118-126. doi:10.1016/j.biochi.2017.01.006

Chapple, C.R., (null), L., Nitti, V.W., Siddiqui, E., Michel, M.C., 2014a. Mirabegron in overactive bladder: a review of efficacy, safety, and tolerability. Neurourol. Urodyn. 33, 17-30. doi:10.1002/nau.22505

Chapple, C.R., Kaplan, S.A., Mitcheson, D., Blauwet, M.B., Huang, M., Siddiqui, E., Khullar, V., $2014 b$. Mirabegron $50 \mathrm{mg}$ once-daily for the treatment of symptoms of overactive bladder: an overview of efficacy and tolerability over 12 weeks and 1 year. Int. J. Urol. 21, 960-967. doi:10.1111/iju.12568

Chapple, C.R., Siddiqui, E., 2017. Mirabegron for the treatment of overactive bladder: a review of efficacy, safety and tolerability with a focus on male, elderly and antimuscarinic poor-responder populations, and patients with $\mathrm{OAB}$ in Asia. Expert Rev Clin Pharmacol 10, 131-151. doi:10.1080/17512433.2017.1275570

Clinton, L.K., Billings, L.M., Green, K.N., Caccamo, A., Ngo, J., Oddo, S., McGaugh, J.L., LaFerla, F.M., 2007. Age-dependent sexual dimorphism in cognition and stress response in the 3xTg-AD mice. Neurobiology of Disease 28, 76-82. doi:10.1016/j.nbd.2007.06.013

Consoli, D., Leggio, G.M., Mazzola, C., Micale, V., Drago, F., 2007. Behavioral effects of the beta3 adrenoceptor agonist SR58611A: is it the putative prototype of a new class of antidepressant/anxiolytic drugs? Eur. J. Pharmacol. 573, 139-147. doi:10.1016/j.ejphar.2007.06.048

Craft, S., Baker, L.D., Montine, T.J., Minoshima, S., Watson, G.S., Claxton, A., Arbuckle, M., Callaghan, M., Tsai, E., Plymate, S.R., Green, P.S., Leverenz, J., Cross, D., Gerton, B., 2012. Intranasal insulin therapy for Alzheimer disease and amnestic mild cognitive impairment: a pilot clinical trial. Arch. Neurol. 69, 29-38. doi:10.1001/archneurol.2011.233

Cypess, A.M., Lehman, S., Williams, G., Tal, I., Rodman, D., Goldfine, A.B., Kuo, F.C., Palmer, E.L., Tseng, Y.-H., Doria, A., Kolodny, G.M., Kahn, C.R., 2009. Identification and importance of brown adipose tissue in adult humans. N. Engl. J. Med. 360, 1509-1517. doi:10.1056/NEJMoa0810780

Cypess, A.M., Weiner, L.S., Roberts-Toler, C., Franquet Elía, E., Kessler, S.H., Kahn, P.A., English, J., Chatman, K., Trauger, S.A., Doria, A., Kolodny, G.M., 2015. Activation of human brown adipose tissue by a $\beta 3$-adrenergic receptor agonist. Cell Metabolism 21, 33-38. doi:10.1016/j.cmet.2014.12.009

Dal-Pan, A., Dudonné, S., Bourassa, P., Bourdoulous, M., Tremblay, C., Desjardins, Y., Calon, F., Neurophenols consortium, 2016. Cognitive-Enhancing Effects of a Polyphenols-Rich Extract from Fruits without Changes in Neuropathology in an Animal Model of Alzheimer's Disease. J. Alzheimers 
Dis. Preprint, 1-21. doi:10.3233/JAD-160281

Danysz, W., Han, Y., Li, F., Nicoll, J., Buch, P., Hengl, T., Ruitenberg, M., Parsons, C., 2018. Browning of white adipose tissue induced by the $\beta 3$ agonist CL-316,243 after local and systemic treatment - PKPD relationship. Biochim. Biophys. Acta. doi:10.1016/j.bbadis.2018.06.007

de Souza, C.J., Hirshman, M.F., Horton, E.S., 1997. CL-316,243, a beta3-specific adrenoceptor agonist, enhances insulin-stimulated glucose disposal in nonobese rats. Diabetes 46, 1257-1263.

Degroot, D.W., Kenney, W.L., 2007. Impaired defense of core temperature in aged humans during mild cold stress. AJP: Regulatory, Integrative and Comparative Physiology 292, R103-8. doi:10.1152/ajpregu.00074.2006

Do, K., Laing, B.T., Landry, T., Bunner, W., Mersaud, N., Matsubara, T., Li, P., Yuan, Y., Lu, Q., Huang, H., 2018. The effects of exercise on hypothalamic neurodegeneration of Alzheimer's disease mouse model. PLoS ONE 13, e0190205. doi:10.1371/journal.pone.0190205

Do, T.M., Alata, W., Dodacki, A., Traversy, M.-T., Chacun, H., Pradier, L., Scherrmann, J.-M., Farinotti, R., Calon, F., Bourasset, F., 2014. Altered cerebral vascular volumes and solute transport at the bloodbrain barriers of two transgenic mouse models of Alzheimer's disease. Neuropharmacology 81, 311-317. doi:10.1016/j.neuropharm.2014.02.010

Do, T.M., Dodacki, A., Alata, W., Calon, F., Nicolic, S., Scherrmann, J.-M., Farinotti, R., Bourasset, F., 2016. Age-Dependent Regulation of the Blood-Brain Barrier Influx/Efflux Equilibrium of Amyloid- $\beta$ Peptide in a Mouse Model of Alzheimer's Disease (3xTg-AD). J. Alzheimers Dis. 49, 287-300. doi:10.3233/JAD-150350

Donahue, J.E., Flaherty, S.L., Johanson, C.E., Duncan, J.A., Silverberg, G.D., Miller, M.C., Tavares, R., Yang, W., Wu, Q., Sabo, E., Hovanesian, V., Stopa, E.G., 2006. RAGE, LRP-1, and amyloid-beta protein in Alzheimer's disease. Acta Neuropathol 112, 405-415. doi:10.1007/s00401-006-0115-3

Evans, B.A., Papaioannou, M., Bonazzi, V.R., Summers, R.J., 1996. Expression of beta 3-adrenoceptor mRNA in rat tissues. 117, 210-216.

Farris, W., Mansourian, S., Chang, Y., Lindsley, L., Eckman, E.A., Frosch, M.P., Eckman, C.B., Tanzi, R.E., Selkoe, D.J., Guenette, S., 2003. Insulin-degrading enzyme regulates the levels of insulin, amyloid beta-protein, and the beta-amyloid precursor protein intracellular domain in vivo. Proc. Natl. Acad. Sci. U.S.A. 100, 4162-4167. doi:10.1073/pnas.0230450100

Gavrilova, O., Marcus-Samuels, B., Reitman, M.L., 2000. Lack of responses to a beta3-adrenergic agonist in lipoatrophic A-ZIP/F-1 mice. Diabetes 49, 1910-1916.

Gejl, M., Gjedde, A., Egefjord, L., Møller, A., Hansen, S.B., Vang, K., Rodell, A., Brændgaard, H., Gottrup, H., Schacht, A., Møller, N., Brock, B., Rungby, J., 2016. In Alzheimer's Disease, 6-Month Treatment with GLP-1 Analog Prevents Decline of Brain Glucose Metabolism: Randomized, Placebo-Controlled, Double-Blind Clinical Trial. Front Aging Neurosci 8, 108. doi:10.3389/fnagi.2016.00108

Ghorbani, M., Shafiee Ardestani, M., Gigloo, S.H., Cohan, R.A., Inanlou, D.N., Ghorbani, P., 2012. Anti diabetic effect of $C L 316,243$ (a $\beta 3$-adrenergic agonist) by down regulation of tumour necrosis factor (TNF- $\alpha$ ) expression. 7, e45874. doi:10.1371/journal.pone.0045874

Gibbs, M.E., Maksel, D., Gibbs, Z., Hou, X., Summers, R.J., Small, D.H., 2010. Memory loss caused by beta-amyloid protein is rescued by a beta(3)-adrenoceptor agonist. Neurobiol. Aging 31, 614-624. doi:10.1016/j.neurobiolaging.2008.05.018

Gomolin, I.H., Aung, M.M., Wolf-Klein, G., Auerbach, C., 2005. Older is colder: temperature range and variation in older people. J Am Geriatr Soc 53, 2170-2172. doi:10.1111/j.1532-5415.2005.00500.x

Grassi, G., Seravalle, G., Turri, C., Bertinieri, G., Dell'Oro, R., Mancia, G., 2003. Impairment of thermoregulatory control of skin sympathetic nerve traffic in the elderly. Circulation 108, 729-735. doi:10.1161/01.CIR.0000081769.02847.A1

Gratuze, M., Julien, J., Petry, F.R., Morin, F., Planel, E., 2017. Insulin deprivation induces PP2A inhibition and tau hyperphosphorylation in hTau mice, a model of Alzheimer's disease-like tau pathology. 
Nature Publishing Group 7, 46359. doi:10.1038/srep46359

Gunstad, J., Lhotsky, A., Wendell, C.R., Ferrucci, L., Zonderman, A.B., 2010. Longitudinal examination of obesity and cognitive function: results from the Baltimore longitudinal study of aging. Neuroepidemiology 34, 222-229. doi:10.1159/000297742

Hanssen, M.J.W., Hoeks, J., Brans, B., van der Lans, A.A.J.J., Schaart, G., van den Driessche, J.J., Jörgensen, J.A., Boekschoten, M.V., Hesselink, M.K.C., Havekes, B., Kersten, S., Mottaghy, F.M., van Marken Lichtenbelt, W.D., Schrauwen, P., 2015. Short-term cold acclimation improves insulin sensitivity in patients with type 2 diabetes mellitus. Nat. Med. 21, 863-865. doi:10.1038/nm.3891

Hebda-Bauer, E.K., Simmons, T.A., Sugg, A., Ural, E., Stewart, J.A., Beals, J.L., Wei, Q., Watson, S.J., Akil, H., 2013. 3xTg-AD mice exhibit an activated central stress axis during early-stage pathology. J. Alzheimers Dis. 33, 407-422. doi:10.3233/JAD-2012-121438

Hebert, L.E., Weuve, J., Scherr, P.A., Evans, D.A., 2013. Alzheimer disease in the United States (20102050) estimated using the 2010 census. Neurology 80, 1778-1783. doi:10.1212/WNL.0b013e31828726f5

Huitrón-Reséndiz, S., Sánchez-Alavez, M., Gallegos, R., Berg, G., Crawford, E., Giacchino, J.L., Games, D., Henriksen, S.J., Criado, J.R., 2002. Age-independent and age-related deficits in visuospatial learning, sleep-wake states, thermoregulation and motor activity in PDAPP mice. Brain Res. 928, 126-137.

Iqbal, K., Liu, F., Gong, C.-X., 2016. Tau and neurodegenerative disease: the story so far. Nat Rev Neurol 12, 15-27. doi:10.1038/nrneurol.2015.225

Jacobsen, J.S., Wu, C.-C., Redwine, J.M., Comery, T.A., Arias, R., Bowlby, M., Martone, R., Morrison, J.H., Pangalos, M.N., Reinhart, P.H., Bloom, F.E., 2006. Early-onset behavioral and synaptic deficits in a mouse model of Alzheimer's disease. Proc. Natl. Acad. Sci. U.S.A. 103, 5161-5166. doi:10.1073/pnas.0600948103

Julien, C., Tremblay, C., Bendjelloul, F., Phivilay, A., Coulombe, M.-A., Emond, V., Calon, F., 2008. Decreased drebrin mRNA expression in Alzheimer disease: correlation with tau pathology. J. Neurosci. Res. 86, 2292-2302. doi:10.1002/jnr.21667

Julien, C., Tremblay, C., Phivilay, A., Berthiaume, L., Emond, V., Julien, P., Calon, F., 2010. High-fat diet aggravates amyloid-beta and tau pathologies in the 3xTg-AD mouse model. Neurobiol. Aging 31, 1516-1531. doi:10.1016/j.neurobiolaging.2008.08.022

Kalaria, R.N., Harik, S.I., 1989. Reduced glucose transporter at the blood-brain barrier and in cerebral cortex in Alzheimer disease. Journal of Neurochemistry 53, 1083-1088.

Kim, H., Pennisi, P.A., Gavrilova, O., Pack, S., Jou, W., Setser-Portas, J., East-Palmer, J., Tang, Y., Manganiello, V.C., Leroith, D., 2006. Effect of adipocyte beta3-adrenergic receptor activation on the type 2 diabetic MKR mice. Am. J. Physiol. Endocrinol. Metab. 290, E1227-36. doi:10.1152/ajpendo.00344.2005

Knight, E.M., Brown, T.M., Gümüsgöz, S., Smith, J.C.M., Waters, E.J., Allan, S.M., Lawrence, C.B., 2013. Age-related changes in core body temperature and activity in triple-transgenic Alzheimer's disease (3xTgAD) mice. Dis Model Mech 6, 160-170. doi:10.1242/dmm.010173

Kumar, A., Shiloach, J., Betenbaugh, M.J., Gallagher, E.J., 2015. The beta-3 adrenergic agonist (CL$316,243)$ restores the expression of down-regulated fatty acid oxidation genes in type 2 diabetic mice. Nutr Metab (Lond) 12, 8. doi:10.1186/s12986-015-0003-8

Kumar-Singh, S., Theuns, J., Van Broeck, B., Pirici, D., Vennekens, K., Corsmit, E., Cruts, M., Dermaut, B., Wang, R., Van Broeckhoven, C., 2006. Mean age-of-onset of familial alzheimer disease caused by presenilin mutations correlates with both increased Abeta42 and decreased Abeta40. Hum. Mutat. 27, 686-695. doi:10.1002/humu.20336

Labbé, S.M., Caron, A., Chechi, K., Laplante, M., Lecomte, R., Richard, D., 2016. Metabolic activity of brown, "beige," and white adipose tissues in response to chronic adrenergic stimulation in male mice. Am. J. Physiol. Endocrinol. Metab. 311, E260-8. doi:10.1152/ajpendo.00545.2015 
Leger, M., Quiedeville, A., Bouet, V., Haelewyn, B., Boulouard, M., Schumann-Bard, P., Freret, T., 2013. Object recognition test in mice. Nat Protoc 8, 2531-2537. doi:10.1038/nprot.2013.155

Liu, J., Wang, L.-N., Jia, J.-P., 2015. Peroxisome proliferator-activated receptor-gamma agonists for Alzheimer's disease and amnestic mild cognitive impairment: a systematic review and meta-analysis. Drugs Aging 32, 57-65. doi:10.1007/s40266-014-0228-7

Liu, Y., Liu, F., Iqbal, K., Grundke-lqbal, I., Gong, C.-X., 2008. Decreased glucose transporters correlate to abnormal hyperphosphorylation of tau in Alzheimer disease. FEBS Lett. 582, 359-364. doi:10.1016/j.febslet.2007.12.035

Loh, R.K.C., Formosa, M.F., La Gerche, A., Reutens, A.T., Kingwell, B.A., Carey, A.L., 2018. The acute metabolic and cardiovascular effects of mirabegron in healthy individuals. Diabetes Obes Metab. doi:10.1111/dom.13516

Nam, M., Cooper, M.P., 2015. Role of Energy Metabolism in the Brown Fat Gene Program. Front Endocrinol (Lausanne) 6, 104. doi:10.3389/fendo.2015.00104

Nedergaard, J., Cannon, B., 2013. UCP1 mRNA does not produce heat. Biochim. Biophys. Acta 1831, 943-949. doi:10.1016/j.bbalip.2013.01.009

Nedergaard, J., Golozoubova, V., Matthias, A., Asadi, A., Jacobsson, A., Cannon, B., 2001. UCP1: the only protein able to mediate adaptive non-shivering thermogenesis and metabolic inefficiency. Biochim. Biophys. Acta 1504, 82-106.

Nicholson, R.M., Kusne, Y., Nowak, L.A., LaFerla, F.M., Reiman, E.M., Valla, J., 2010. Regional cerebral glucose uptake in the 3xTG model of Alzheimer's disease highlights common regional vulnerability across AD mouse models. Brain Res. 1347, 179-185. doi:10.1016/j.brainres.2010.05.084

Oddo, S., Caccamo, A., Shepherd, J.D., Murphy, M.P., Golde, T.E., Kayed, R., Metherate, R., Mattson, M.P., Akbari, Y., LaFerla, F.M., 2003. Triple-Transgenic Model of Alzheimer's Disease with Plaques and Tangles. Neuron 39, 409-421. doi:10.1016/S0896-6273(03)00434-3

Planel, E., Richter, K.E.G., Nolan, C.E., Finley, J.E., Liu, L., Wen, Y., Krishnamurthy, P., Herman, M., Wang, L., Schachter, J.B., Nelson, R.B., Lau, L.-F., Duff, K.E., 2007. Anesthesia leads to tau hyperphosphorylation through inhibition of phosphatase activity by hypothermia. J Neurosci 27 , 3090-3097. doi:10.1523/JNEUROSCI.4854-06.2007

Poher, A.-L., Veyrat-Durebex, C., Altirriba, J., Montet, X., Colin, D.J., Caillon, A., Lyautey, J., RohnerJeanrenaud, F., 2015. Ectopic UCP1 Overexpression in White Adipose Tissue Improves Insulin Sensitivity in Lou/C Rats, a Model of Obesity Resistance. Diabetes 64, 3700-3712. doi:10.2337/db15-0210

Querfurth, H.W., LaFerla, F.M., 2010. Alzheimer's disease. N. Engl. J. Med. 362, 329-344. doi:10.1056/NEJMra0909142

Rajasekar, N., Nath, C., Hanif, K., Shukla, R., 2017. Intranasal insulin improves cerebral blood flow, Nrf-2 expression and BDNF in STZ (ICV)-induced memory impaired rats. Life Sci. 173, 1-10. doi:10.1016/j.lfs.2016.09.020

Ravussin, Y., Xiao, C., Gavrilova, O., Reitman, M.L., 2014. Effect of intermittent cold exposure on brown fat activation, obesity, and energy homeostasis in mice. 9, e85876. doi:10.1371/journal.pone.0085876

Scheltens, P., Blennow, K., Breteler, M.M.B., De Strooper, B., Frisoni, G.B., Salloway, S., Van der Flier, W.M., 2016. Alzheimer's disease. Lancet 388, 505-517. doi:10.1016/S0140-6736(15)01124-1

Schrauwen, P., van Marken Lichtenbelt, W.D., 2016. Combatting type 2 diabetes by turning up the heat. Diabetologia 59, 2269-2279. doi:10.1007/s00125-016-4068-3

Selkoe, D.J., Hardy, J., 2016. The amyloid hypothesis of Alzheimer's disease at 25 years. EMBO Mol Med 8, 595-608. doi:10.15252/emmm.201606210

Simpson, I.A., Chundu, K.R., Davies-Hill, T., Honer, W.G., Davies, P., 1994. Decreased concentrations of GLUT1 and GLUT3 glucose transporters in the brains of patients with Alzheimer's disease. Ann. 
Neurol. 35, 546-551. doi:10.1002/ana.410350507

St-Amour, I., Paré, I., Tremblay, C., Coulombe, K., Bazin, R., Calon, F., 2014. IVIg protects the 3xTg-AD mouse model of Alzheimer's disease from memory deficit and $A \beta$ pathology. J Neuroinflammation 11, 54. doi:10.1186/1742-2094-11-54

Stemmelin, J., Cohen, C., Terranova, J.-P., Lopez-Grancha, M., Pichat, P., Bergis, O., Decobert, M., Santucci, V., Françon, D., Alonso, R., Stahl, S.M., Keane, P., Avenet, P., Scatton, B., Le Fur, G., Griebel, G., 2008. Stimulation of the beta3-Adrenoceptor as a novel treatment strategy for anxiety and depressive disorders. Neuropsychopharmacology 33, 574-587. doi:10.1038/sj.npp.1301424

Sterniczuk, R., Dyck, R.H., LaFerla, F.M., Antle, M.C., 2010. Characterization of the 3xTg-AD mouse model of Alzheimer's disease: part 1. Circadian changes. Brain Res. 1348, 139-148. doi:10.1016/j.brainres.2010.05.013

Stieler, J.T., Bullmann, T., Kohl, F., Tøien, Ø., Brückner, M.K., Härtig, W., Barnes, B.M., Arendt, T., 2011. The physiological link between metabolic rate depression and tau phosphorylation in mammalian hibernation. 6, e14530. doi:10.1371/journal.pone.0014530

Summers, R.J., Papaioannou, M., Harris, S., Evans, B.A., 1995. Expression of beta 3-adrenoceptor mRNA in rat brain. 116, 2547-2548.

Szentirmai, É., Kapás, L., 2017. The role of the brown adipose tissue in $\beta 3$-adrenergic receptor activationinduced sleep, metabolic and feeding responses. Nature Publishing Group 7, 958. doi:10.1038/s41598-017-01047-1

Takeda, S., Sato, N., Uchio-Yamada, K., Sawada, K., Kunieda, T., Takeuchi, D., Kurinami, H., Shinohara, M., Rakugi, H., Morishita, R., 2010. Diabetes-accelerated memory dysfunction via cerebrovascular inflammation and Abeta deposition in an Alzheimer mouse model with diabetes. Proc. Natl. Acad. Sci. U.S.A. 107, 7036-7041. doi:10.1073/pnas.1000645107

Tamburella, A., Micale, V., Leggio, G.M., Drago, F., 2010. The beta3 adrenoceptor agonist, amibegron (SR58611A) counteracts stress-induced behavioral and neurochemical changes. Eur Neuropsychopharmacol 20, 704-713. doi:10.1016/j.euroneuro.2010.04.006

Tanzi, R.E., 2012. The genetics of Alzheimer disease. Cold Spring Harb Perspect Med 2, a006296a006296. doi:10.1101/cshperspect.a006296

Theriault, P., ElAli, A., Rivest, S., 2016. High fat diet exacerbates Alzheimer's disease-related pathology in APPswe/PS1 mice. Oncotarget 5. doi:10.18632/oncotarget.12179

Tong, X.-K., Trigiani, L.J., Hamel, E., 2019. High cholesterol triggers white matter alterations and cognitive deficits in a mouse model of cerebrovascular disease: benefits of simvastatin. Cell Death Dis 10, 89. doi:10.1038/s41419-018-1199-0

Tournissac, M., Bourassa, P., Martinez-Cano, R.D., Vu, T.-M., Hébert, S.S., Planel, E., Calon, F., 2019. Repeated cold exposures protect a mouse model of Alzheimer's disease against cold-induced tau phosphorylation. Molecular Metabolism 22, 110-120. doi:10.1016/j.molmet.2019.01.008

Tournissac, M., Vandal, M., Francois, A., Planel, E., Calon, F., 2017. Old age potentiates cold-induced tau phosphorylation: linking thermoregulatory deficit with Alzheimer's disease. Neurobiol. Aging 50, 25-29. doi:10.1016/j.neurobiolaging.2016.09.024

Tremblay, C., Francois, A., Delay, C., Freland, L., Vandal, M., Bennett, Calon, F., 2017. Association of Neuropathological Markers in the Parietal Cortex With Antemortem Cognitive Function in Persons With Mild Cognitive Impairment and Alzheimer Disease. J. Neuropathol. Exp. Neurol. doi:10.1093/jnen/nlw109

Tremblay, C., Pilote, M., Phivilay, A., Emond, V., Bennett, Calon, F., 2007. Biochemical characterization of Abeta and tau pathologies in mild cognitive impairment and Alzheimer's disease. J. Alzheimers Dis. 12, 377-390.

Vandal, M., White, P.J., Chevrier, G., Tremblay, C., St-Amour, I., Planel, E., Marette, A., Calon, F., 2015. Age-dependent impairment of glucose tolerance in the 3xTg-AD mouse model of Alzheimer's 
disease. FASEB J. 29, 4273-4284. doi:10.1096/fj.14-268482

Vandal, M., White, P.J., Tournissac, M., Tremblay, C., St-Amour, I., Drouin-Ouellet, J., Bousquet, M., Traversy, M.-T., Planel, E., Marette, A., Calon, F., 2016. Impaired thermoregulation and beneficial effects of thermoneutrality in the 3xTg-AD model of Alzheimer's disease. Neurobiol. Aging 43, 4757. doi:10.1016/j.neurobiolaging.2016.03.024

Vandal, M., White, P.J., Tremblay, C., St-Amour, I., Chevrier, G., Emond, V., Lefrançois, D., Virgili, J., Planel, E., Giguere, Y., Marette, A., Calon, F., 2014. Insulin reverses the high-fat diet-induced increase in brain $a \beta$ and improves memory in an animal model of Alzheimer disease. Diabetes 63, 4291-4301. doi:10.2337/db14-0375

Virtanen, K.A., Lidell, M.E., Orava, J., Heglind, M., Westergren, R., Niemi, T., Taittonen, M., Laine, J., Savisto, N.-J., Enerbäck, S., Nuutila, P., 2009. Functional brown adipose tissue in healthy adults. N. Engl. J. Med. 360, 1518-1525. doi:10.1056/NEJMoa0808949

Weinert, D., Waterhouse, J., Nevill, A., 2004. Changes of Body Temperature and Thermoregulation in the Course of the Ovarian Cycle in Laboratory Mice. Biological Rhythm Research 35, 171-185. doi:10.1080/09291010412331335724

Weyer, C., Tataranni, P.A., Snitker, S., Danforth, E., Ravussin, E., 1998. Increase in insulin action and fat oxidation after treatment with $\mathrm{CL} 316,243$, a highly selective beta3-adrenoceptor agonist in humans. Diabetes 47, 1555-1561.

Winblad, B., Amouyel, P., Andrieu, S., Ballard, C., Brayne, C., Brodaty, H., Cedazo-Minguez, A., Dubois, B., Edvardsson, D., Feldman, H., Fratiglioni, L., Frisoni, G.B., Gauthier, S., Georges, J., Graff, C., Iqbal, K., Jessen, F., Johansson, G., Jönsson, L., Kivipelto, M., Knapp, M., Mangialasche, F., Melis, R., Nordberg, A., Rikkert, M.O., Qiu, C., Sakmar, T.P., Scheltens, P., Schneider, L.S., Sperling, R., Tjernberg, L.O., Waldemar, G., Wimo, A., Zetterberg, H., 2016. Defeating Alzheimer's disease and other dementias: a priority for European science and society. Lancet Neurol 15, 455-532. doi:10.1016/S14744422(16)00062-4

Wolf, A., Bauer, B., Abner, E.L., Ashkenazy-Frolinger, T., Hartz, A.M.S., 2016. A Comprehensive Behavioral Test Battery to Assess Learning and Memory in 129S6/Tg2576 Mice. PLoS ONE 11, e0147733. doi:10.1371/journal.pone.0147733

Xiao, C., Goldgof, M., Gavrilova, O., Reitman, M.L., 2015. Anti-obesity and metabolic efficacy of the $\beta 3$ adrenergic agonist, CL316243, in mice at thermoneutrality compared to $22^{\circ} \mathrm{C}$. Obesity (Silver Spring) 23, 1450-1459. doi:10.1002/oby.21124

Yarchoan, M., Arnold, S.E., 2014. Repurposing diabetes drugs for brain insulin resistance in Alzheimer disease. Diabetes 63, 2253-2261. doi:10.2337/db14-0287

Yoshida, T., Sakane, N., Wakabayashi, Y., Umekawa, T., Kondo, M., 1994. Anti-obesity and anti-diabetic effects of CL 316,243, a highly specific beta 3-adrenoceptor agonist, in yellow KK mice. Life Sci. 54, 491-498. 